\title{
Forging a Partnership Between the China and the World in an Era of Division: Finding Common Ground in Climate Change and Health
}

\author{
Kerry Brown
}

\begin{abstract}
Public perceptions about China on social media outside of China often resemble a field of battle, but in words. Some users and groups produce endless statements bolstering their conviction that China is the epitome of wickedness. Others push out equivalent amounts that look remarkably like Chinese propaganda saying nothing but good things about the People's Republic. The crucial space for neutrality seems to be closing down. This acknowledges, both for the US and EU, the acceptance that a radical difference in viewpoints on China has to proceed alongside a similarly crucial admission that it would be self-defeating not to work with China. Comprehensive dis-engagement with China is not an option. Whatever the problems with China, those involving human impact on the environment causing climate change and combating global public health issues are far more serious. The first poses, in the longer term, an existential threat to humanity. The stark reality is that a solution to this issue will not happen without partners like China, and it is likely that China will be a huge part of whatever ultimate solution must be found.
\end{abstract}

Keywords Social media and China $\cdot$ China is the epitome of wickedness $\cdot$ Chinese propaganda $\cdot$ Radical difference in viewpoints on China $\cdot$ Self-defeating not to work with China $\cdot$ Comprehensive dis-engagement with China is not an option • Existential threat to humanity

If anyone wanted to check the temperature gauge in early 2021 on public perceptions on China and its relations with the outside world, all they needed to do is to scroll through Twitter. Debates about issues relating to China often resembled a civil war in words unfolding on social media. Some users and groups produced endless statements and pieces of evidence bolstering their conviction that the current government and political system in China is the epitome of wickedness. Others pushed out equivalent amounts that look remarkably like propaganda saying that nothing but good emanates from the People's Republic. Finding an island of peace between these fiercely clashing forces is getting harder. The crucial space for neutrality seems to be closing down.

\footnotetext{
K. Brown ( $\bowtie)$

Lau China Institute, King's College London, London, UK

(C) The Author(s) 2021

H. Wang and A. Michie (eds.), Consensus or Conflict?, China and Globalization, https://doi.org/10.1007/978-981-16-5391-9_4
} 
Public opinion in the UK is a useful barometer for this. Surveys in the period before 2020 were sparse. They mostly showed either indifference on the part of the UK towards China, or a focus simply on economic matters. Even during the 'golden age', as the Chinese labelled this, during Chinese President Xi Jinping's visit to Britain in late 2015, the dial did not seem to shift much. As someone from Britain who dealt with China as a diplomat and then academic since 1994, I was also struck by this strange incongruity-visits to China showed a place over this period that was transforming almost by the second. But the China story in the UK was best characterised as a very static one. It was broadly split, at least in the media, between 'China is a human rights hell hole' on the one hand, and on the other 'this place is getting wealthier by the minute-let's go make money from them'! This remained the default for almost the entire period from the mid-1990s onwards.

The prominence given to the first cases of COVID-19 being observed in China in late 2019 and the spread of the pandemic across the world have changed this, though it is an interesting question about how deep and enduring that change will prove to be. In Europe and the US politicians, who never showed great interest in the place that a fifth of humanity call home and by 2020 accounted for a similar proportion of global GDP, suddenly had strong opinions about the world's largest country still practicing communism. China figured as a suitable object of anger, blame and, in the more extreme cases, hate. Ex-President Donald Trump declared on his Twitter that COVID-19 was 'the China virus'. Even the populist politician in the UK, Nigel Farage, ${ }^{1}$ stated that, having dealt with the European Union (EU) issue through Brexit in the UK, he was now going to focus on the threat from China. The shift from a sort of complacent indifference, to active antipathy seemed sharp and dramatic.

\section{Moderate Places}

What is striking over this time, however, from someone who had to observe this issue of China's relations with the world almost every day, was the acknowledgement away from the noisy platforms on which figures had to posture publicly to get attention, that the issue humanity was facing was far more complex that this almost Manichean mentality being deployed towards China indicated. Officials and public opinion formers (even if they were self-appointed!) were more than happy to concede this crucial fact, albeit in private. The tone of their remarks was often far more questioning and circumspect. This was backed up by one reasonably good quality survey undertaken by the British Foreign Policy Group towards the end of 2020 and published in 2021. It showed that on the whole, while those over 55 in the UK had a measurably dimmer view of China than in previous years, younger people were more positive. ${ }^{2}$ There was, even now, no straightforward consensus.

\footnotetext{
${ }^{1}$ https://www.dailymail.co.uk/debate/article-9282657/NIGEL-FARAGE-Communist-takeoverschools-Britain-end-once.html published 21 February 2021.

${ }^{2}$ Gaston and Aspinall (2021).
} 
This complexity was reflected in the ruling Conservative Party's evolving position on China. The Prime Minister, Boris Johnson, deployed the word 'sinophile' a number of times in 2020. His government continued to declare that there were rich opportunities in doing business with China. After all, in the era of 'Global Britain', after the UK formally left the EU and the Customs Union in 2020, it was natural to look at the fastest growing, major economy, and one that, according to official data, the UK was doing more and more business with-and had potential to do far more. ${ }^{3}$ Alongside this, however, were important factions in the Conservative Party who established a 'China Research Group' ${ }^{4}$ in mid-2020 which, in effect, operated as a lobbying group for a far harder line on China because of issues in Hong Kong, reports of repression in Xinjiang, and elsewhere. The imposition of the National Security Law in Hong Kong in July 2020 was a particular trigger for harsh words from the Foreign Secretary, Dominic Raab, about the Chinese government. There were plenty of other cases of this manifestation of sometimes furious antagonism between the two governments as the year proceeded.

That there was even a small moderate middle space, even as these arguments intensified for Britain, Europe and the US, in particular, which was important for the very simple reason that for all the legitimate concerns about the places where China increasingly didn't align to Western interests and expectations, and in some of the most important (perhaps the most important) areas, there was plenty to work together on. Of these, areas concerning climate change, sustainability, public health and economic recovery after the pandemic were at the front. In all of these, China figured as a largely collaborative partner-even if this was more about potential than actuality. The key thing was that the possibility was there. That meant that those figuring about the best approach to China, once they steered clear of the extremes alluded to above, had to somehow craft a policy which recognised the real issues between much of the world and China, but also balanced these with the equally large areas of common interest and necessary cooperation.

\section{Outline of the Issue}

One of the crucial things to accept, when contemplating this imperative of seeking balance and finding a meaningful middle space to work from, was to have consensus on the nature of the problem in the first place. One issue about US or European views on China was that it was haunted by a frustration verging on anger that, despite decades of 'engagement' on the economic front, there had been no political returns on this. China continued with its one-party system, with the Communist Party under $\mathrm{Xi}$ seeking to make this sustainable and permanent. The fundamental issue for the most critical groups in the West was that it seemed this ambition was proceeding well in China. Speculation about the stability and security of the regime abounded.

\footnotetext{
${ }^{3}$ Ward (2020).

${ }^{4}$ https://chinaresearchgroup.org.
} 
Maybe there were deep fault lines that external observers just weren't seeing, but a sober assessment had to admit that, for all the issue about how the pandemic was first handled when it appeared in China over 2019, and into 2020, compared to many in developed countries, some of whom were its fiercest critics, the Xi government had ended up managing the crisis well. By the time of the National People's Congress in March 2021, economic growth had been restored, and, as far as anyone could tell, the health crisis had been largely dealt with. This had all ended up reinforcing Xi's dominance, rather than eroding it. That too was antagonising to the most implacable of his critics.

In the era when economic engagement with the goal of political change by actors from the US outwards had clearly ended up simply not delivering in the case of China, and regardless of the complex reasons behind this, it was clear that some of the fundamental assumptions about both the global order and about China's role, in particular, in it needed to be rethought. There were a few factors by which to undertake this exercise.

The first was simply to accept that the People's Republic of China's accrual of vast amounts of material wealth in the last few decades would inevitably and increasingly translate into geopolitical influence. This was not to claim that all of this accrual had happened as something designed by anyone. China might not have intended to have this much new power, and might not even want it, but the fact was that simply being as large as it was economically meant that this was a fact regardless of whether China or anyone else liked it.

The second was to understand that there was no easy model for the outside world to use to understand how best to interpret China's intentions and strategies. This is a good antidote to the group that like to employ moral absolutes towards China and demand it be ethically condemned for what it is in and of itself. We have dealt with a Communist run superpower - the USSR — but not with a Communist run superpower that is also a supremely successful practitioner of capitalism. China's hybridity, whereby it mixes political, cultural and economic elements that often seem incompatible, disorientates the outside world, meaning that there is no easy singletrack response that will wholly work. Perhaps the 'frenemy' term coined a decade or so go-neither a friend nor an enemy-captures this situation the best. In this situation, bringing in some existing template to understand and manage things won't work. We have to create something fresh. That at least explains some of the messiness of the current moment.

The third was to stress the need for some strategic caution. Commitment to one image of what China currently is (an ideological and values competitor seeking to change the outside world to look like it), and one notion of what it is up to (military dominance) means that the other options (of China being ideologically exceptionalist and largely driven by self-interest while not wanting the responsibility of dominance) get pushed into the background, even though this might, in some areas, and in some ways, have validity. China operates on different layers, some of which fit the first response, and in others by the others. The desire to commit wholly to one attitude and one approach, which easier and more straightforward for American and European 
policy making mores, means that attempts to 'manage' or 'deal' with the challenge end up being partial and sometimes self-defeating.

All of this makes it easy to see why China's challenge is such a tricky one. The dominant mindset in the most powerful blocs in the world (the US, EU) is to operate in terms of universals, to be seeking a singular 'truth' and to feel that behind complexity there must ultimately like some foundational, unitary reality. That probably hails from the positivist understanding of the world that served so well during the scientific revolution and into the industrial revolution in Europe, since the 17th century. China's challenge in the end is not military, economic or as a human rights actor. The principal issue is its ontological complexity. This lies at the root of all the other issues. It is multiple things - capitalist and communist, old (as a culture) and new (as a state), Confucian and Marxist. That means that dealing with a complex issue in simple ways, when that problem is small, might work. China today is so large as an issue that it demands to be dealt with on its own terms. That necessitates a hybrid response. For lovers of uniformity and unity, this is almost heretical. But if we want to come to terms with how to view China, heresy is what we need to embrace and practice.

We can maintain the current dominant mindset that China is to be transformed, or conquered, or utterly eschewed. China has been on a transformation path for 40 years and it is clear that whatever transformation China might experience, it will not end up aligning with models that have emerged elsewhere. The USSR's collapse should make us less blithely confident we can know what we will end up with, and worried that it will be far worse than what we had! Conquering is also beyond the bounds of reason. China is a nuclear power and contains a fifth of the human race. Any attempts at forcing decisions on it will end up in conflict that will almost certainly be catastrophic for everyone. Eschewing China by decoupling might be the only vaguely viable option. But even here, climate change, public health and other global issues means that willingly or not, China is a partner that has to be worked with, if for no other reason than the outside world's self-interest. All this means that one change that might work is to lay down the activist and proselytising proclivities of the US and Europe, and simply adopt a more pragmatic attitude of acceptance towards China. It is as it is, with the values and the system it currently has. The main thing is to seek common ground, where at least some changes at a more local level might happen (to both, if we are being even handed about this) rather than place unilateral, comprehensive change in the country right at the start, and at the head of everything else. This might seem just a matter of change of attitude-but attitudes are hugely important, and at least in this case, the agency is with those outside China to change their own minds and frameworks.

We do have to accord some sympathy to the outside world in view of all of this. It is easy to understand why the current predicament is a hard one for Western policymakers and politicians. Communicating a hybrid response to a public which often has little knowledge or background of this vast new, and very different, partner is a huge challenge. This is especially the case when that partner also has a way of operating that is perpetually ambiguous on key issues, and often highly antagonistic on matters like Hong Kong, Xinjiang and Taiwan. The outcome for those trying to communicate 
means they are often left being daubed with crude labels like 'appeaser', 'apologist' or 'cold war warrior'.

The events of 2020 and into 2021, however, have made one thing clear-the fact of China. For example, of China being a fifth of global GDP and likely increases to this after the impact of COVID-19 on other major economies, of its geographical vastness and key strategic position, and of its decisive impact on environmental and other global common issues - these facts do not change. What needs to change is the response to this. Mindsets and frameworks are key. So is intellectual and conceptual clarity about spelling out with precision where China is a problem, why it is a problem and how that problem can be managed. We cannot solve the issue of China. We can, however, manage it. At the moment, too many are striving for the former task, which is probably impossible, and meaning that we have less and less time to focus on the latter, which is possible.

\section{The Change Is Starting}

In a lucid discussion of the various divisions and arguments in democratic societies, author Ian Leslie ${ }^{5}$ outlines the genesis of some of the most intractable and problematic disputes. These, he shows, usually blow up from a refusal by one party to see any validity in that of the other, which has the toxic result of then causing them to stick even more closely to their own view. The issue is the threat to their status and identity, rather than anything the argument might, on the surface at least, be about.

Of course, the number of actors and the complexity of issues between China and its main international interlocutors means that the parallels between individual arguments and national, geopolitical ones, shouldn't be overstretched. Leslie, however, does show that even in the most violent clashes of view and opinion, there are pathways that can be created where people can be guided, or guide themselves, back to the middle ground, and do so with a recognition of mutual self-interest foremost in their minds.

In some ways, the world in early 2021, after the economic and health ravages of the pandemic, looks like it is a place where, geopolitically, some kind of extraterrestrial mediator needs to arrive to carry out the sort of work that Leslie describes is undertaken by earthly counsellors and negotiators. Despite the gloomy feelings around the current moment, however, there should be two things that at least provide a little light at the end of the tunnel-at least as far as China's relations with the outside world go.

The first is that with the arrival of the Biden Administration from January 2021, and the EU's position over 2020, embedded in their position is an implicit acknowledgement that rather than a single policy framework by which to understand and work with (or against) China, there is a multi-level approach. This at least goes some way to capturing the complexity referred to in the section above. Anthony Blinken,

${ }^{5}$ Leslie (2020). 
the US Secretary of State, in a speech on foreign policy in March 2021, delivered shortly after his appointment, used the phrase 'Our relationship with China will be competitive when it should be, collaborative when it can be, and adversarial when it must be' ${ }^{6}$ This strangely echoed the trilateral division the European Union who, in a strategic paper issued in March 2019, had presciently stated that:

China is, simultaneously, in different policy areas, a cooperation partner with whom the $E U$ has closely aligned objectives, a negotiating partner with whom the EU needs to find a balance of interests, an economic competitor in the pursuit of technological leadership, and a systemic rival promoting alternative models of governance. This requires a flexible and pragmatic whole-of-EU approach. ${ }^{7}$

This acknowledges, both for the US and EU, the acceptance that a radical difference in viewpoints with China has to proceed alongside a similarly crucial admission that it would be self-defeating not to work with China. Comprehensive disengagement therefore, despite the language used in some quarters, was not and could not be an option.

There was a simple reason for this, which brings us to the second structural factor. Whatever the problems with China, and however significant they were, those involving human impact on the environment causing climate change, and combating global public health issues (as COVID-19 showed), were far more serious. The first posed, in the longer term, an existential threat to humanity. Indeed, Toby Ord, in a fascinating study of the greatest calamities that might face humankind in the coming decades, put the threat from Artificial Intelligence even higher. ${ }^{8}$ In all these issues, China stood in the same critical position as everyone else. Indeed, on climate change, the deterioration of water and air quality in China had been an increasingly important concern for citizens since the turn of the millennium. Unlike the US, it had stayed committed to the Paris Agreement of 2015, rather than temporarily withdrawing. The Climate Change Conference (COP26) in November 2021 only underlines this, with China a key attendee. The stark reality is that a solution to this issue will not happen without partners like China, and, more positively, it is likely that China will be a huge part of whatever ultimate solution must be found.

These areas of common interest and alignment act as the basis for cooperation. They are acknowledged in the language used by the US and EU about common areas where there is strategic alignment, as quoted above. The political reality is that no government acting rationally and responsibly would, or could, jeapordise working together on these global issues for those which are more local, no matter how important they are. This is not to denigrate or deny the concerns about Hong Kong, Xinjiang and other issues, but it does place them in a crucial context. However

\footnotetext{
${ }^{6}$ Clarissa Yong, 'Biden Administration Establishes China Competition as Key Strategic Focus', March 4, Strait Times, https://www.straitstimes.com/world/united-states/us-secretary-of-state-ant ony-blinken-calls-china-biggest-test-vows-us-strength.

${ }^{7}$ European Commission and HR/VP contribution to the European Council, 'EU-China - A strategic outlook', March 2019, https://ec.europa.eu/info/sites/info/files/communication-eu-china-a-strate gic-outlook.pdf, page 1 .

${ }^{8}$ Ord (2020).
} 
strong feelings are on these, there has to be a pragmatic framing. Granting the illusion of choice is for solipsists and daydreamers. All contact and discussion with China now have to happen in a framework that acknowledges the parameters supplied by global, common problems that threaten the very future of the human race, and where China and the rest of the world stand in the same place.

This means that it is not a matter of choice to live with the multi-level, multidimensional approach to China that the US and EU have had to adopt since 2019. This will be a feature of diplomacy for the foreseeable future. It is not elegant, and it certainly violates the usual desire to have a neat, holistic framework by which to deal with things. But in many areas, we are used to speaking the language of spectrums, where there are no orderly boundaries dividing issues. That sort of spectrum framework with China is the new normal. And for all its complexity, at least it makes things workable and manageable. Not win-win, for sure, but at the very least not lose either, which is something at least to celebrate in a world often looking overwhelmed by its own sense of divisions and strife.

\section{References}

Gaston S, Aspinall E (2021) UK foreign policy and global affairs: annual survey 2021, issued 2021. https://bfpg.co.uk/wp-content/uploads/2021/02/BFPG-Annual-Survey-2021.pdf

Leslie I (2020) Conflicted XE "Leslie, Ian" : why arguments are tearing us apart and how they can bring us together. Faber, London

Ord T (2020) The precipice XE "Ord, Toby" : existential risk and the future of humanity. Bloomsbury, London

Ward M (2020) Statistics on UK Trade with China, UK Parliament, House of Commons Library, 14 July 2020, https://commonslibrary.parliament.uk/research-briefings/cbp-7379/\#: :text=In\% $202019 \% 3$ A,deficit $\% 20$ of $\% 20 \% 2 \mathrm{D} \% \mathrm{C} 2 \%$ A318.3\%20billion.\&text=China\%20accounted $\%$ 20for $\% 204.4 \% 25 \% 20$ of,fourth $\% 20$ largest $\% 20$ source $\% 20$ of $\% 20$ imports.

Kerry Brown is a Professor of Chinese Studies and Director of the Lau China Institute, King's College London. From 2012 to 2015, he was Professor of Chinese Politics and Director of the China Studies Centre at the University of Sydney, Australia. Prior to this, he worked at Chatham House (2006 to 2012) as Senior Fellow and then Head of the Asia Programme. From 1998 to 2005, he worked at the British Foreign and Commonwealth Office, and as First Secretary at the British Embassy in Beijing. He is the author of over ten books on modern Chinese politics, history and language. 
Open Access This chapter is licensed under the terms of the Creative Commons AttributionNonCommercial-NoDerivatives 4.0 International License (http://creativecommons.org/licenses/bync-nd/4.0/), which permits any noncommercial use, sharing, distribution and reproduction in any medium or format, as long as you give appropriate credit to the original author(s) and the source, provide a link to the Creative Commons license and indicate if you modified the licensed material. You do not have permission under this license to share adapted material derived from this chapter or parts of it.

The images or other third party material in this chapter are included in the chapter's Creative Commons license, unless indicated otherwise in a credit line to the material. If material is not included in the chapter's Creative Commons license and your intended use is not permitted by statutory regulation or exceeds the permitted use, you will need to obtain permission directly from the copyright holder.

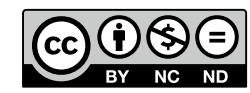

